\title{
Description of Neblinichthys peniculatus, a new species of loricariid catfish from the río Paragua drainage of Venezuela
}

\author{
Jonathan W. Armbruster ${ }^{1}$ and Donald C. Taphorn ${ }^{2}$
}

Neblinichthys peniculatus is described from specimens collected in the río Carapo (río Paragua - río Caroni drainage), which drains the southern flank of Cerro Guaiquinima in southeastern Venezuela. Neblinichthys peniculatus differs from all congeners by having mottling on the caudal peduncle consisting of dark spots and dashes (vs. caudal peduncle all about the same color or light below and dark above) and by having spots on the head (spots less conspicuous in nuptial males as the head is darker; vs. no spots). Uniquely among Neblinichthys for which nuptial males are known, the hypertrophied odontodes on the snout are rather short, none as large as the eye diameter.

Se describe una nueva especie, Neblinichthys peniculatus, con especímenes colectados del río Carapo (cuenca del río Paragua-rio Caroní), que drena el flanco sur del Cerro Guaiquinima en el sureste de Venezuela. Neblinichthys peniculatus difiere de todos sus congéneres en tener un patrón de pigmentación moteado en el pedúnculo caudal, que consiste de puntos y líneas cortas oscuras ( $v s$. pedúnculo caudal más o menos uniformemente pigmentado, más oscuro dorsalmente y más claro ventralmente) y por tener puntos en la cabeza (los puntos son menos conspicuos en los machos nupciales; vs. cabeza sin puntos). Los odontodos hipertrofiados del hocico son cortos en los machos nupciales y ninguno es tan largo como el diámetro del ojo, una condición única entre las especies de Neblinichthys de las cuales se conocen los machos nupciales.

Key words: Ancistrini, Caroni, Guiana Shield, Hypostominae, Punk catfish.

\section{Introduction}

Neblinichthys was originally described as a new genus from specimens collected from a stream that drains Pico Neblina in southern Venezuela (Ferraris et al., 1986). Since that time, three other species were described in the genus, and Ancistrus yaravi Steindachner was recognized as belonging to Neblinichthys (Provenzano et al., 1995; Taphorn et al., 2010). Neblinichthys is a member of the Ancistrus clade of the Ancistrini, (Hypostominae), and was found to either be a member of a polytomy of all Ancistrus clade except Pseudancistrus (Armbruster, 2004) or as sister to all Ancistrus clade members except Dekeyseria and Pseudancistrus (Armbruster, 2008); however, support for any relationships of Neblinichthys within the Ancistrus clade is weak.

Species of Neblinichthys are known for their extremely large odontodes on the snouts of nuptial males (nuptial males of $N$. yaravi and fully developed males of $N$. brevibracchium Taphorn, Armbruster, López-Fernández \& Bernard, are not known), which are directed anterodorsally in $N$. pilosus Ferraris, Isbrücker \& Nijssen and N. roraima Provenzano, Lasso \&
Ponte and largely anteriorly in N. echinasus Taphorn, Armbruster, López-Fernández \& Bernard. The genus ranges across the Western Guiana Shield in small streams; however, a giant gap in the range occurs from Pico Neblina to the upper Caroni. This gap is at least partially bridged by specimens collected in the middle río Paragua, a tributary of the río Caroni in eastern Venezuela (Fig. 1). These specimens differ in color and morphometrics from other Neblinichthys and are described here as a new species.

\section{Material and Methods}

Counts and measurements follow Armbruster (2003); barbel length is zero if the barbel is completely adnate (does not extend beyond lip). Museum acronyms follow Leviton et al. (1985). Names of plate rows follow Schaefer (1997). Specimens were sexed according to Ballen \& Vari (2012) with mature females having a broad genital papilla with flaps around the aperture and males having a longer, pointed genital papilla; the male papilla corresponds with having hypertrophied odontodes on the snout. A principal

${ }^{1}$ Department of Biological Sciences and Auburn University Museum of Natural History, 331 Funchess, Auburn, AL 36849, USA. armbrjw@auburn.edu

${ }^{2} 1822$ N. Charles St., Belleville, IL, USA. taphorn@gmail.com 


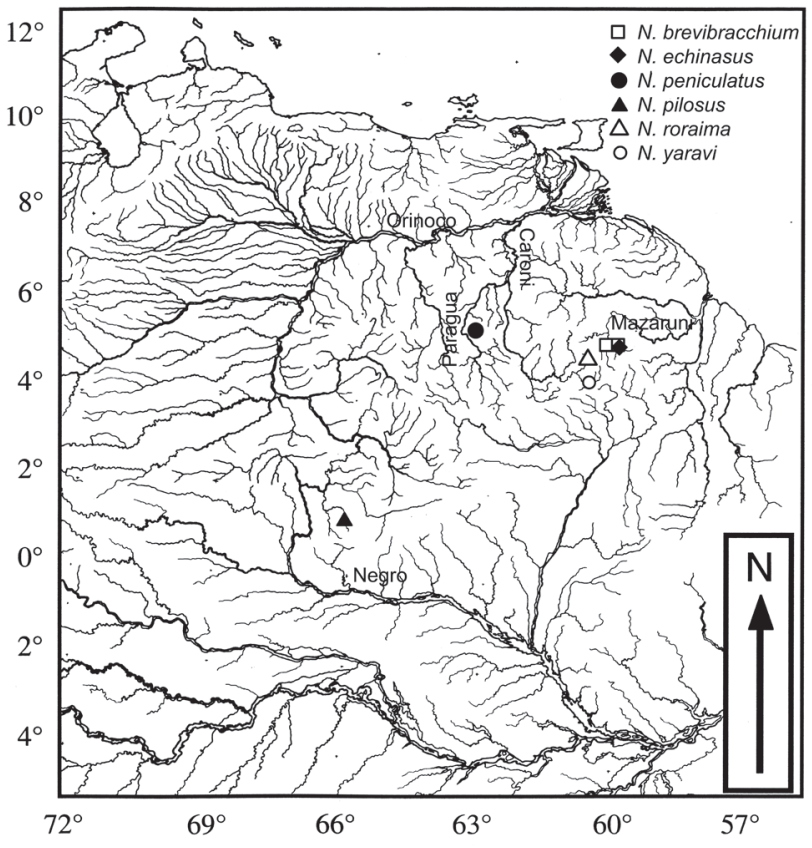

Fig. 1. Distribution of Neblinichthys. Main drainages where the species are located indicated. Symbols may represent multiple localities. components analysis for the morphometric data was performed using a covariate matrix and log-transformed measurements in JMP (Vers. 5.01a, SAS Institute, 2002). Principal component one was excluded from further analysis because it represented overall size difference ( $v s$. relative size difference). Comparative material is listed in Taphorn et al. (2010). There was an error in tables of Taphorn et al. (2010), and "\% Head Length" is actually "\% Predorsal Length". Correct values are in Table 1 .

\section{Key to the species of Neblinichthys}

1a. Four or more preadipose plates; 10 or fewer elongate cheek odontodes N. roraima

1b. Three or fewer preadipose plates, 20 or more elongate cheek odontodes .....

2a. Abdomen with irregular gray spots and vermiculations on a dark background; no (occasionally one) odontodes on the exposed portion of the opercle; iris operculum absent, internares width $5.0-8.5 \% \mathrm{HL}$

$2 \mathrm{~b}$. Abdomen usually white or with dark spots or short vermiculations on a light background; 10 or more odontodes on the exposed portion of the opercle, iris operculum present; internares width 7.6-15.5\% HL ......... 4

3a. Dorsal-fin base length 18.1-22.8\% SL; dorsal-anal distance $13.7-18.3 \% \mathrm{SL}$, snout decreasing in steep arc just anterior

Table 1. Morphometric features of the heads as percentage of HL for Neblinichthys brevibracchium ( $\mathrm{N}=23$, except $\mathrm{SL}, \mathrm{N}=$ 29), N. echinasus $(\mathrm{N}=3), N$. pilosus $(\mathrm{N}=6), N$. roraima $(\mathrm{N}=4)$, and $N$. yaravi $(\mathrm{N}=8$, except anal-fin spine $\mathrm{L}$. and interorbital $\mathrm{W}$., $\mathrm{N}=7$ ). Landmarks are the numbered landmarks in Armbruster (2003). Some $N$. roraima have completely adnate barbels, giving a measurement of zero. Revised from Taphorn et al. (2010) where these measurements were inadvertently published as ratios of predorsal length.

\begin{tabular}{|c|c|c|c|c|c|}
\hline \multirow[b]{2}{*}{ Landmarks } & \multirow[b]{2}{*}{ Feature } & \multicolumn{2}{|c|}{ N. brevibracchium } & \multicolumn{2}{|c|}{ N. echinasus } \\
\hline & & Range & Avg. \pm SD & Range & Avg. \pm SD \\
\hline $5-7$ & Head-eye L. & $34.0-40.7$ & $36.4 \pm 1.4$ & $33.0-38.6$ & $36.2 \pm 2.9$ \\
\hline $4-5$ & Orbit Dia. & $14.3-17.2$ & $15.8 \pm 0.8$ & $14.9-19.3$ & $17.8 \pm 2.5$ \\
\hline $1-4$ & Snout L. & $52.6-62.8$ & $59.3 \pm 2.5$ & $60.2-63.3$ & $61.6 \pm 1.6$ \\
\hline $2-3$ & Internares $\mathrm{W}$. & $6.5-11.4$ & $8.2 \pm 1.0$ & $8.1-9.1$ & $8.6 \pm 0.5$ \\
\hline $5-6$ & Interorbital W. & $47.8-54.5$ & $50.9 \pm 1.7$ & $52.5-55.7$ & $54.2 \pm 1.6$ \\
\hline $7-12$ & Head Dp. & $54.5-83.9$ & $61.9 \pm 4.9$ & $56.5-59.6$ & $58.4 \pm 1.7$ \\
\hline $1-24$ & Mouth L. & $47.8-61.7$ & $53.8 \pm 3.3$ & $56.8-57.8$ & $57.4 \pm 0.5$ \\
\hline $21-22$ & Mouth W. & $45.2-55.1$ & $50.4 \pm 2.6$ & $53.2-56.2$ & $54.6 \pm 1.5$ \\
\hline $22-23$ & Barbel L. & $1.1-4.4$ & $3.0 \pm 0.9$ & $1.9-2.9$ & $2.3 \pm 0.5$ \\
\hline $25-26$ & Dentary tooth cup L. & $10.9-17.5$ & $14.7 \pm 1.4$ & $11.4-16.4$ & $13.5 \pm 2.7$ \\
\hline \multirow[t]{2}{*}{$27-28$} & Premaxillary tooth cup L. & $10.9-16.7$ & $13.6 \pm 1.4$ & $10.7-13.6$ & $12.5 \pm 1.6$ \\
\hline & & \multicolumn{2}{|c|}{ N. roraima } & \multicolumn{2}{|c|}{ N. yaravi } \\
\hline Landmarks & Feature & Range & Avg. \pm SD & Range & Avg. \pm SD \\
\hline $5-7$ & Head-eye L. & $34.2-41.9$ & $39.7 \pm 3.7$ & $33.7-38.6$ & $37.1 \pm 1.5$ \\
\hline $4-5$ & Orbit Dia. & $14.4-17.2$ & $16.2 \pm 1.2$ & $15.8-18.5$ & $17.4 \pm 0.9$ \\
\hline $1-4$ & Snout L. & $54.9-61.9$ & $58.5 \pm 2.9$ & $55.1-64.7$ & $59.3 \pm 3.0$ \\
\hline $2-3$ & Internares W. & $12.3-15.0$ & $13.8 \pm 1.2$ & $9.3-11.8$ & $10.4 \pm 0.9$ \\
\hline $5-6$ & Interorbital W. & - & - & $48.0-56.2$ & $52.8 \pm 2.7$ \\
\hline $7-12$ & Head Dp. & $61.3-63.4$ & $62.5 \pm 0.9$ & $61.2-66.8$ & $63.3 \pm 1.7$ \\
\hline $1-24$ & Mouth L. & $49.6-64.0$ & $54.9 \pm 6.3$ & $51.4-61.3$ & $54.3 \pm 3.5$ \\
\hline $21-22$ & Mouth W. & $53.7-66.0$ & $62.0 \pm 5.8$ & $54.3-64.0$ & $60.5 \pm 3.4$ \\
\hline $22-23$ & Barbel L. & $0.0-4.3$ & $1.8 \pm 2.2$ & $1.7-3.6$ & $2.7 \pm 0.6$ \\
\hline $25-26$ & Dentary tooth cup L. & $17.5-25.3$ & $20.4 \pm 3.4$ & $16.7-19.3$ & $17.6 \pm 0.9$ \\
\hline $27-28$ & Premaxillary tooth cup L. & $19.4-24.6$ & $21.0 \pm 2.4$ & $14.9-20.1$ & $16.5 \pm 1.7$ \\
\hline
\end{tabular}


to eyes and then flattening in area anterior of nares; adpressed dorsal fin not reaching anterior preadipose plate N. brevibracchium

3b. Dorsal-fin base length 24.3-27.0\% SL; dorsal-anal distance $11.9-12.5 \% \mathrm{SL}$, snout tapering shallowly and continuously from eyes to snout tip; adpressed dorsal fin reaching anterior preadipose plate. N. echinasus

4a. Usually four anal-fin rays (one examined with five), spots on fins small dashes confined to rays; six to seven columns of spots on caudal fin ................................................... yaravi

$4 \mathrm{~b}$. Five anal-fin rays; spots on fins large and round, extending onto membranes; three to five bands or columns of spots on caudal fin .

5a. Caudal peduncle with dark blotches forming mottling; head usually with spots (absent in nuptial males); rectangular blotch at base of caudal fin; nuptial males with relatively short odontodes directed largely upwards (see discussion); internares width 10.5-12.4\% HL; postanal length 28.5-30.6\% SL N. peniculatus

5b. Caudal peduncle brown; head without spots; no rectangular blotch at base of caudal fin; nuptial males with very long odontodes directed anteriorly (see discussion); internares width 17.3-20.1\% HL; postanal length 32.8-34.9\% SL N. pilosus

\section{Neblinichthys peniculatus, new species Figs. 2-4, Table 2}

Holotype. MBUCV V-35680, $78.8 \mathrm{~mm}$ SL, male, Venezuela, Bolivar, río Paragua drainage, río Carapo at first rapids along right bank, 541'51'N 6332’30”W, 22 Feb 1990, C. J. Ferraris, A. Machado-A. \& R. Royero (Figs. 2 and 3).

Paratypes. AMNH 255488, 2 (1 male, 1 female), 67.5-78.8 mm SL, AMNH 91020, 71.6 mm SL, female, (Fig. 4), AUM 56753, 1 (male), $71.5 \mathrm{~mm}$ SL, collected with holotype; AMNH 91021, 14 (1 male, 1 female, 1 juvenile, 11 fry), 11.1-81.3 mm SL ( 3 measured, 60.1-81.3 mm SL), MBUCV V-35681, 3, 71.5-76.7 (not measured), Venezuela, Bolivar, río Paragua drainage, río Carapo at third rapids

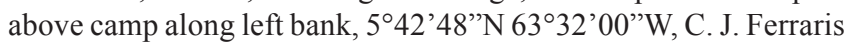
\& R. Royero, 28 February 1990.

Diagnosis. Neblinichthys peniculatus differs from all congeners by having mottling on the caudal peduncle consisting of dark spots and dashes ( $v s$. caudal peduncle all about the same color or light below and dark above; Figs. 2 and 4), by having spots on the head (spots less conspicuous in nuptial males as the head is darker; vs. no spots; Figs. 2 and 4), and by having hypertrophied snout odontodes smaller than orbit diameter (vs. much larger than orbit diameter; nuptial males unknown for $N$. yaravi; see Discussion, Fig. 3); from N. brevibracchium and N. echinasus by having an iris operculum (vs. operculum absent or at most dorsal rim of iris straight), by having odontodes on the opercle ( $v s$. usually zero, but no more than one, odontodes on opercle), and internares 3.9-4.6\% HL (vs. 5.0$8.5 \%$ in $N$. brevibracchium and $6.2-6.7 \%$ in N. echinasus), and by having no spots (or at best very faint spots on a light background) on the abdomen of adult males ( $v s$. large light spots and vermiculations on a dark abdomen); from $N$. pilosus and $N$. yaravi by having a rectangular dark blotch at the base of the caudal fin (vs. blotch absent; Figs. 2 and 4); from N. pilosus by internares width $10.5-12.4 \% \mathrm{HL}$ ( $v s$. 17.3-20.1\%), and postanal length $28.5-30.6 \%$ SL (vs. 32.8$34.9 \%$ ); from $N$. roraima by having a one (occasionally two) preadipose plates with the adipose membrane conspicuous ( $v s$. five to nine preadipose plates and the adipose membrane inconspicuous or absent), and greater than 20 evertible cheek odontodes ( $v s .10$ or fewer); from $N$. roraima and $N$. yaravi by having five anal-fin rays ( $v s$. three to four in $N$. roraima and four, one specimen with five, in N. yaravi); and from $N$. yaravi by having large spots on the fins that clearly proceed onto the membranes ( $v s$. small spots only on rays; Figs. 2 and 4), four to five bands or rows of spots in the caudal fin (vs. at least seven; Figs. 2 and 4), and a larger predorsal length/postanal length ratio (150.1-164.6\% vs. 120.1-144.5\%).

Description. Morphometrics presented in Table 1. Meristics based on eight individuals. Largest specimen male: $81.3 \mathrm{~mm} \mathrm{SL}$.

Body dorsoventrally flattened. Caudal peduncle laterally compressed. Profile from tip of snout to dorsal-fin origin convex. Orbits slightly elevated above head profile. Deepest point of body just anterior to dorsal fin. Profile straight or gently concave to adipose-fin origin, then slightly concave to base of upper caudal-fin spine. Ventral surface flat or slightly concave from just behind oral disk to anal-fin origin then straight to base of lower caudal spine. Eyes widely separated, laterally oriented, not visible from below. Snout broad and rounded. Body widest at pectoral-fin origin, then narrowing gently to origin of pelvic fins, then narrowing more quickly to caudal fin.

Anterior margin and dorsal surface of snout with small odontodes except in nuptial males (see Sexual dimorphism). Cheek plates strongly evertible (to $90^{\circ}$ from head), cheek odontodes relatively long and numerous ( 45-80), longest reaches to level of pectoral-fin spine insertion. Iris operculum absent, making dorsal rim of pupil round.

Mouth moderate in size with narrow premaxillary and dentary tooth cups forming gentle arcs; dentigerous surfaces of dentary slightly smaller than premaxillary. Premaxillary teeth 49-90; dentary teeth 53-80. Teeth villiform and bicuspid with very short cusps (medial cusp longer than lateral). Edge of oral disk largely smooth, extending to vertical through anterior margin of eye, not extending beyond lateral margins of head. Enlarged central papilla present in buccal cavity. Maxillary barbel short, just reaching base of evertible cheek plates. Ventral surface of lips papillose. Papillae largest in center of lower lip, decreasing radially. No enlarged papillae located behind dentary teeth.

Dorsal fin II,7; exposed portion of dorsal-fin spinelet flat with few, short odontodes. Dorsal fin short, not 


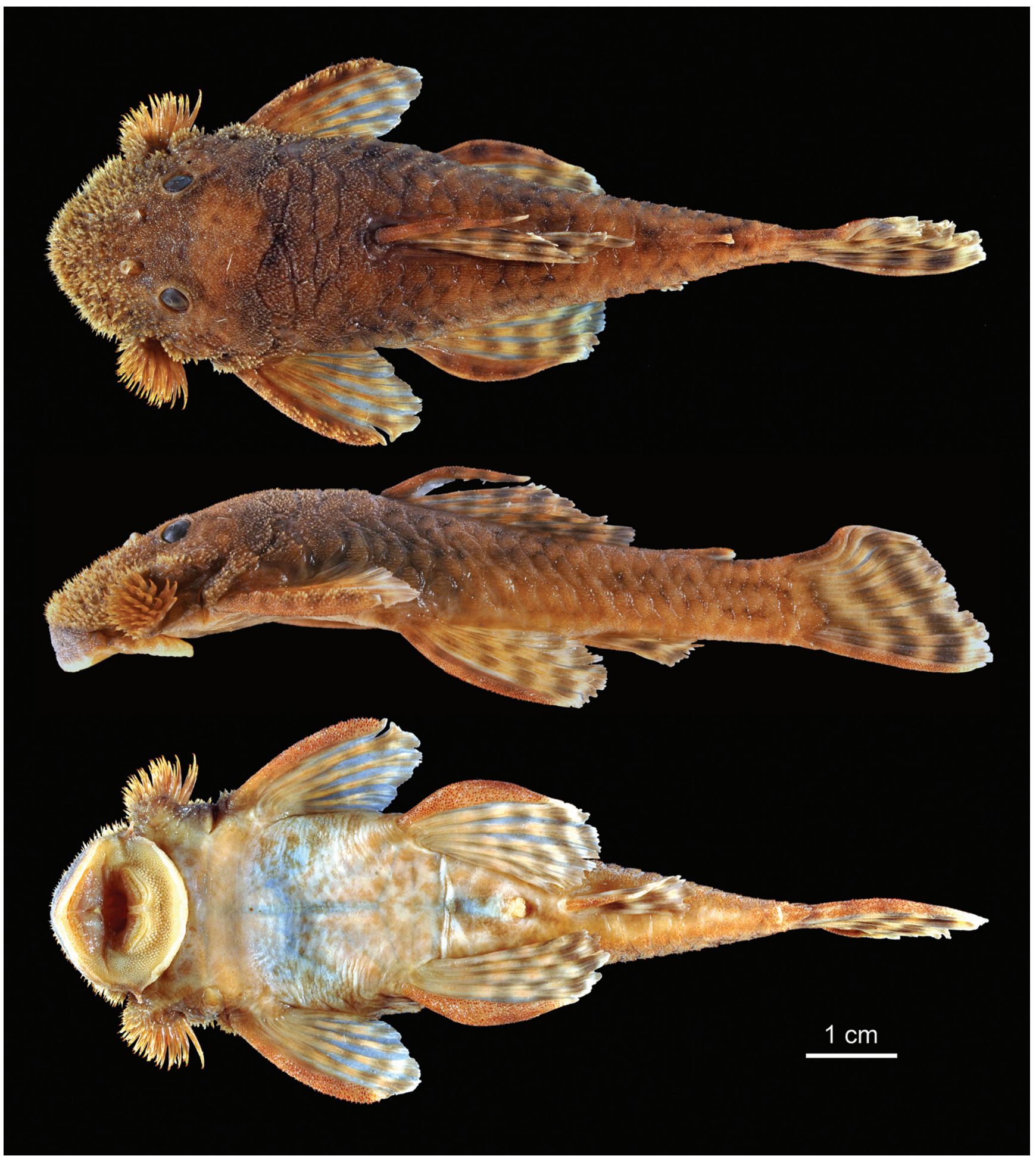

Fig. 2. Dorsal, lateral, and ventral views of Neblinichthys peniculatus, holotype, male, MBUCV V-35680, 78.8 mm SL, Venezuela, Bolivar, río Paragua drainage, río Carapo at first rapids along right bank.

reaching preadipose plate when adpressed. First dorsalfin ray slightly longer than dorsal-fin spine. Pectoral fin I,6. Pectoral-fin spine short (about equal to pelvic-fin spine), reaching insertion of first branched pelvic-fin ray when adpressed ventral to pelvic fin; narrow but strong, numerous odontodes of equal size present along entire length in females, but odontodes becoming larger distally in nuptial males. Anterior pectoral-fin rays longer than 


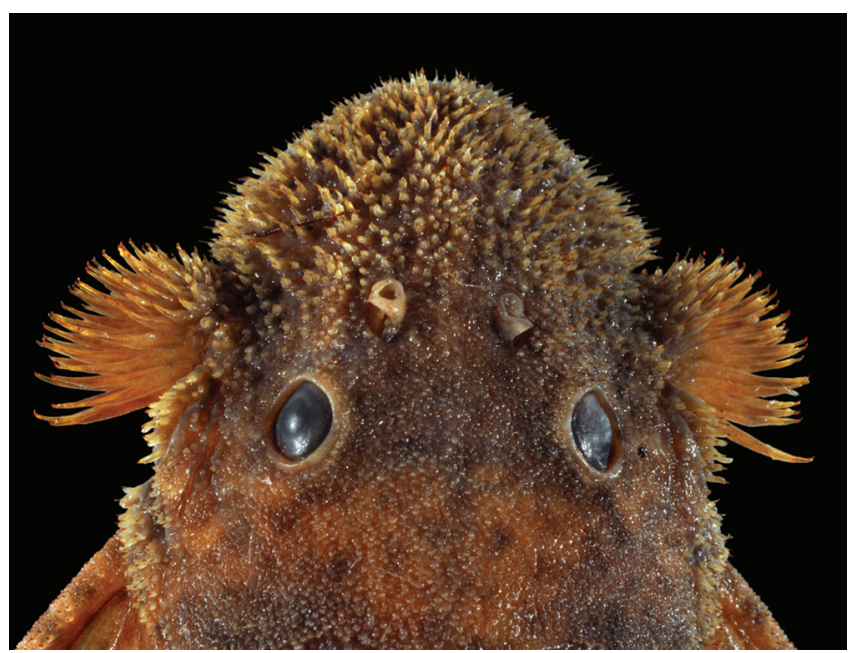

Fig. 3. Dorsal view of head of holotype of Neblinichthys peniculatus, MBUCV V-35680, $78.8 \mathrm{~mm} \mathrm{SL}$.

pectoral-fin spine, decreasing to about half of length of spine posteriorly, covered with odontodes, largest on dorsal surface. Pelvic fin I,5; spine thickened and covered with odontodes, reaching into anterior third of anal-fin base when adpressed; anterior pelvic-fin rays longer than pelvicfin spine with posterior margin of fin curving out beyond posterior tip of spine. Anal fin I,5; all branched anal-fin rays slightly longer than unbranched ray; unbranched ray with odontodes to about three quarters of its length. First anal-fin pterygiophore not exposed to form plate-like structure. Adipose-fin spine straight to slightly curved posteriorly with adipose membrane extending beyond posterior extent of spine, but some specimens with shortened spine and very small membrane; usually one (two specimens with two) preadipose plates. Caudal fin I,14,I; lower caudal-fin spine slightly longer than upper, edge of caudal fin straight and oblique. Dorsal procurrent caudal-fin rays four or five, ventral procurrent caudal-fin rays three or four. Rays of all fins supporting small odontodes.

Median plate series with 22-24 (mode 23) plates, not counting triangular plates on base of caudal fin. Ventral plates forming gentle arc on caudal peduncle and not forming strong rounded keel. Plates in mid-ventral row weakly arched submedially forming low ridge from cleithrum to posterior insertion of pelvic fin. Three rows of plates on caudal peduncle (mid-dorsal plate series ending at level of adipose fin). Abdomen naked.

Coloration in alcohol. See Figs. 2-4. Head, dorsum of body and sides tan with irregular, darker brown or black spots and blotches; mottling most intense on caudal peduncle; spots best formed on head, although faded in nuptial males. No individuals with regular rows of spots. Ventrum light colored, whitish or light tan with few faint dark spots on periphery in larger specimens. Oral disk with inner papillated surface pale tan; outer anterior margin of upper lip gray-brown. All fin spines and rays with spots centered on rays, but extending onto membranes. Occasionally, spots on fins combine to form bands with three to four bands in caudal fin (may be regular or irregular) and three to four bands in dorsal fin. Rectangular dark blotch present on base of caudal fin. Dark spot present at base of anteriormost dorsal-fin membrane. Dorsal surface with five saddles, usually faint), first under anterior part of dorsal fin, second under posterior part of dorsal fin, third and fourth very narrow on either side of adipose fin, and fifth dorsal extension of rectangular blotch on base of caudal fin. Eleven juveniles examined (11.1-23.7 mm SL), all brown (lighter ventrally) except for faint saddles, rectangular blotch and two other bands in caudal fin and two bands in dorsal fin.

Sexual Dimorphism. See Figs. 2-3 vs. 4. Males with elongated odontodes on dorsal portion of head and cleithrum anteriorly and ventrally from an arc extending from exposed dorsal part of cleithrum, to exposed opercle, to anterior of eye to nares; odontodes longest just anterior to base of evertible cheek plates, anteriorly above center of snout, and on opercle; longest odontode slightly smaller than orbit diameter. Hypertrophied odontodes also present on opercle, and exposed portion of cleithrum. Snout skin appears to thicken prior to emergence of hypertrophied odontodes as some individuals have thickened skin and shorter odontodes. Size of odontodes in holotype appear to be maximum size (see Discussion). Odontodes on head of female not elongated. Males also have odontodes on pectoral-fin spines becoming longer distally ( $v s$. all about same size in females). Dark spots on head faded in males.

Distribution. Known from the río Carapo, a tributary of the middle río Paragua of Venezuela. The río Carapo drains the southern flank of Cerro Guaiquinima. Based on Google Earth, the first rapids complex on the Carapo is at $5^{\circ} 41^{\prime} 51^{\prime \prime} \mathrm{N}$ $63^{\circ} 32^{\prime} 30^{\prime \prime} \mathrm{W}$, and the specimens were collected from $100 \mathrm{~m}$ above the lower extent of the rapids as well as a rapids complex further upstream, the third rapids is likely at $5^{\circ} 42^{\prime} 48^{\prime \prime} \mathrm{N}$ $63^{\circ} 32^{\prime} 00^{\prime \prime} \mathrm{W}$.

Etymology. Adjective from the Latin peniculus for brush, if reference to the brushlike odontodes on the snout.

\section{Discussion}

The holotype of Neblinichthys peniculatus has the longest odontodes of any of the available specimens, but they are still very short (less than orbit diameter; Figs. 2-3) when compared to the species for which nuptial males are known ( N. brevibracchium, N. echinasus, $N$. pilosus, and $N$. roraima). Odontodes develop in a fleshy sheath and 


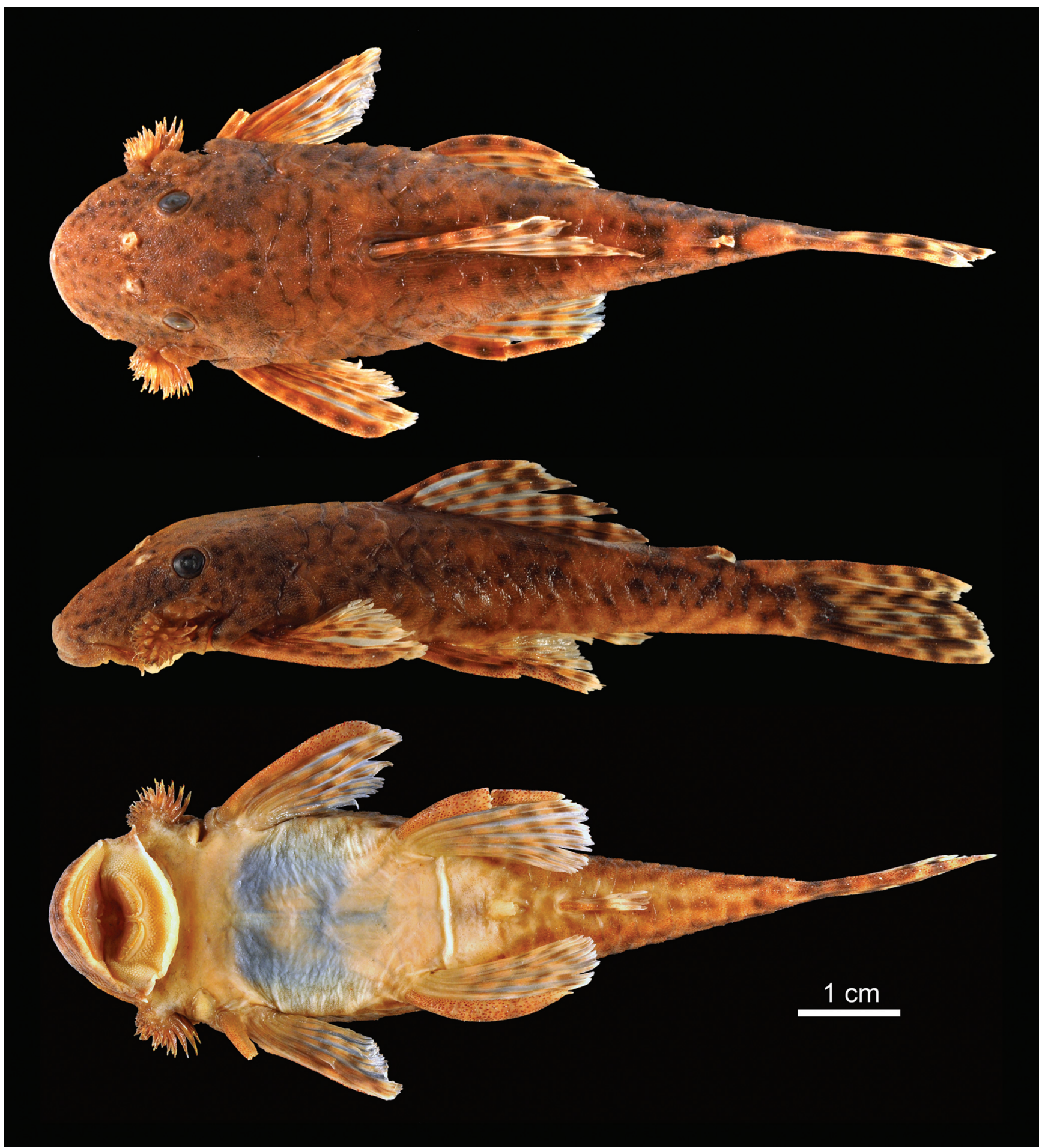

Fig. 4. Dorsal, lateral, and ventral views of Neblinichthys peniculatus, female, paratypes, AMNH 91020, $78.8 \mathrm{~mm}$ SL.

eventually erupt from the sheath often leaving a fleshy flap termed a tentacule next to the odontode (Sabaj et al., 1999). One of us (JWA) has examined hypertrophied odontodes on hundreds of ancistrins, and it appears as if the odontodes grow only for a little while after they erupt. In the holotype, the sheaths are free from the odontodes with small, posterior tentacules present that are slightly shorter than the odontodes. In a paratype of Neblinichthys 
Table 2. Selected morphometric features of Neblinichthys peniculatus $(\mathrm{n}=8)$.

\begin{tabular}{|c|c|c|c|}
\hline & Range & Mean & SD \\
\hline \multirow{2}{*}{\multicolumn{4}{|c|}{$\% \mathrm{SL}$}} \\
\hline & & & \\
\hline Predorsal Length & $44.9-47.7$ & 46.5 & 1.0 \\
\hline Head Length & $33.5-37.2$ & 35.4 & 1.4 \\
\hline Head-dorsal Length & $9.9-11.7$ & 10.9 & 0.7 \\
\hline Cleithral Width & $30.4-34.7$ & 32.2 & 1.4 \\
\hline Head-pectoral Length & $24.5-27.3$ & 26.5 & 0.9 \\
\hline Thorax Length & $23.0-25.8$ & 24.5 & 0.8 \\
\hline Pectoral-spine Length & $23.3-28.1$ & 25.3 & 1.5 \\
\hline Abdominal Length & $24.0-27.1$ & 25.7 & 1.1 \\
\hline Pelvic-spine Length & $23.2-26.9$ & 24.7 & 1.3 \\
\hline Postanal Length & $28.5-30.6$ & 29.6 & 0.7 \\
\hline Anal-fin spine Length & $8.8-13.6$ & 11.0 & 1.6 \\
\hline Dorsal-pectoral Distance & $28.1-31.3$ & 29.4 & 1.1 \\
\hline Dorsal spine Length & $21.9-25.3$ & 23.2 & 1.4 \\
\hline Dorsal-pelvic Distance & $19.8-22.8$ & 21.3 & 1.1 \\
\hline Dorsal-fin base Length & $22.4-25.7$ & 24.3 & 1.0 \\
\hline Dorsal-adipose Distance & $16.7-21.3$ & 19.3 & 1.5 \\
\hline Adipose-spine Length & $4.3-8.6$ & 6.4 & 1.3 \\
\hline Adipose-upper caudal Distance & $11.3-15.1$ & 13.8 & 1.2 \\
\hline Caudal peduncle Depth & $7.9-10.2$ & 9.0 & 0.8 \\
\hline Adipose-lower caudal Distance & $17.3-20.1$ & 18.6 & 0.9 \\
\hline Adipose-anal Distance & $19.4-20.7$ & 20.0 & 0.5 \\
\hline Dorsal-anal Distance & $14.1-15.5$ & 14.6 & 0.5 \\
\hline Pelvic-dorsal Distance & $23.5-28.7$ & 25.5 & 1.9 \\
\hline \multicolumn{4}{|c|}{$\%$ Head Length } \\
\hline Head-eye Length & $35.8-40.7$ & 37.4 & 1.6 \\
\hline Orbit Diameter & $14.2-17.0$ & 15.1 & 0.9 \\
\hline Snout Length & $56.8-61.6$ & 59.6 & 1.8 \\
\hline Internares Width & $10.5-12.4$ & 11.6 & 0.5 \\
\hline Interorbital Width & $46.9-52.4$ & 50.1 & 1.7 \\
\hline Head Depth & $61.0-67.2$ & 64.4 & 2.0 \\
\hline Mouth Length & $49.2-55.1$ & 52.3 & 2.3 \\
\hline Mouth Width & $57.8-79.7$ & 65.2 & 7.3 \\
\hline Barbel Length & $2.9-6.8$ & 4.7 & 1.2 \\
\hline Dentary tooth cup Length & $18.0-24.6$ & 20.7 & 2.3 \\
\hline Premaxillary tooth cup Length & $15.8-20.8$ & 18.3 & 2.1 \\
\hline
\end{tabular}

roraima (MBUCV V-21301; $44.2 \mathrm{~mm} \mathrm{SL}$ ) pictured on the All Catfish Species Inventory website (http://acsi.acnatsci.org/ base/index.html), the odontode sheaths clearly still encase all but the tips of the developing, but still very large, odontodes (the longest appear to be almost equal to the snout-nare distance. Thus, it is likely that if the sheath is free from an odontode, the odontode is at least almost completely developed. In addition, just post-yolk-sac juveniles are part of the type series indicating that the specimens were collected during the breeding season. It would be expected that the odontodes would reach maximum length prior to the breeding season. If the holotype of $N$. peniculatus has fully developed odontodes, $N$. peniculatus can be distinguished from all Neblinichthys for which nuptial males are known by having all hypertrophied odontodes on the snout smaller than orbit diameter ( $v s$. some much larger than orbit diameter). We do not know of any nuptial males of $N$. yaravi.

Neblinichthys probably occurs throughout the Western Guiana Shield, but only at mid-altitude locations, and perhaps only along the flanks of tepuis and other granite outcrops. The locations where the fish have been found so far are some of the more difficult areas to reach as there are few roads, and the fishes occur in smaller streams, making access by boat difficult. The location for Neblinichthys peniculatus is above Salto Uraima, a rather large cataract on the Paragua River, in a sparsely populated region. The stream drains the southern flank of Cerro Guaiquinima, a forested Tepui (Veblen et al., 2007) located due east of Auyan Tepui where Angel Falls is located. The high altitude $(>1500 \mathrm{~m})$ herpetofauna of the Cerro Guaiquinima was found to be most similar to Auyan Tepui (Rödder et al., 2010), and it would be reasonable to expect that a related Neblinichthys would also be found there.

Although we have examined few specimens for morphometrics, the species do segregate in morphospace (Fig. 5). Given that species of the closely related Lasiancistrus show no such segregation with morphometrics over a much larger geographical distance (Armbruster, 2005), and because species Neblinichthys are found in smaller streams draining tepuis, species of Neblinichthys probably segregated long ago, and have adapted to local conditions. A comprehensive phylogeny of species of Neblinichthys would likely be instrumental for studying the development of Western Guiana Shield drainages as outlined in Lujan \& Armbruster (2011); however, this would require collecting in some very remote locations.

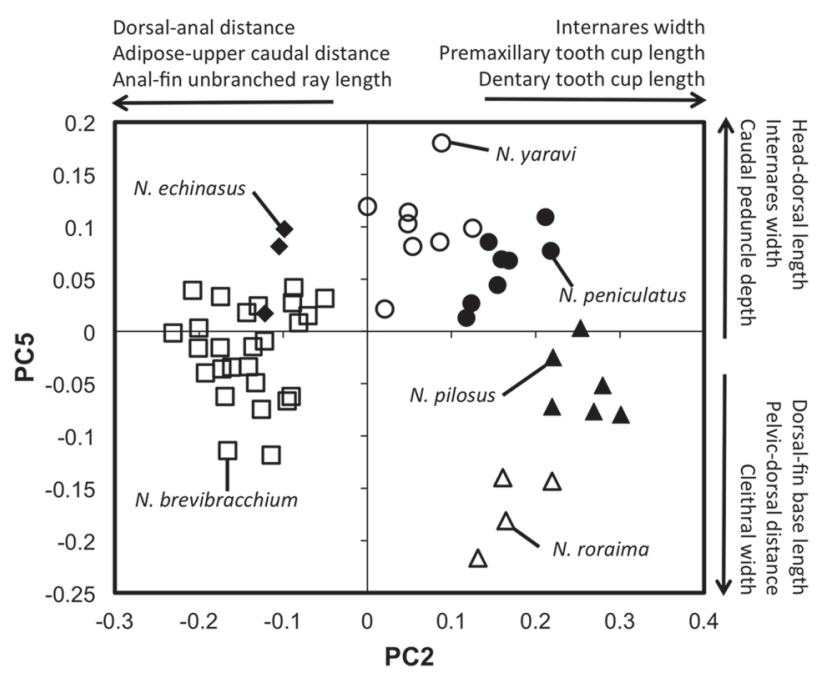

Fig. 5. Principle Components Analysis of species of Neblinichthys. Most strongly loading measurements and their directions indicated. PC2 represents $6.3 \%$ of the total variation and $\mathrm{PC} 5,1.6 \%$ (note, most variation, $81.7 \%$ is in $\mathrm{PC} 1$, which represents overall size). Barbel length was excluded because of extreme variance and interorbital width was excluded because it was not measured the same throughout the study. 


\section{Acknowledgments}

Thanks to S. Schaefer, R. Arrindell, and B. Brown for loan of specimens and M. Sabaj-P., J. Lundberg, and K. Luckenbill (ANSP), O. Crimmen (BMNH), H. Lopéz-F. and E. Holm (ROM), and R. Vari and S. Raredon (USNM) for help when visiting collections or loans of comparative specimens, C. Ferraris for confirming the likelihood of the coordinates for the type locality, and F. Provenzano with help identifying fishes at MBUCV. This project was supported by Planetary Biodiversity Inventory: All Catfish Species (Siluriformes) Phase I of an Inventory of the Otophysi (NSF DEB-0315963) and by NSF grant DEB-0107751 to JWA. Thanks to N. Lujan for calling the fishes to our attention. This paper is Contribution $\mathrm{N}^{\circ} 684$ of the Auburn University Museum of Natural History.

\section{Literature Cited}

Armbruster, J. W. 2003. Peckoltia sabaji, a new species from the Guiana Shield (Siluriformes: Loricariidae). Zootaxa, 344: 1-12.

Armbruster, J. W. 2004. Phylogenetic relationships of the suckermouth armoured catfishes (Loricariidae) with emphasis on the Hypostominae and the Ancistrinae. Zoological Journal of the Linnaean Society, 141: 1-80.

Armbruster, J. W. 2005. The loricariid catfish genus Lasiancistrus (Siluriformes) with description of two new species. Neotropical Ichthyology, 3: 549-569.

Armbruster, J. W. 2008. The genus Peckoltia with the description of two new species and a reanalysis of the phylogeny of the genera of the Hypostominae (Siluriformes: Loricariidae). Zootaxa, 1822: 1-76.

Ballen, G. A. \& R. P. Vari. 2012. Review of the Andean armored catfishes of the genus Dolichancistrus Isbrücker (Siluriformes: Loricariidae). Neotropical Ichthyology, 10: 499-518.

Ferraris, C. J., Jr., I. J. H. Isbrücker \& H. Nijssen. 1986. Neblinichthys pilosus, a new genus and species of mailed catfish from the río Baria system, southern Venezuela (Pisces, Siluriformes, Loricariidae). Revue française d'Aquariologie Herpetologie, 13: 69-72.
Leviton, A. E., R. H. Gibbs Jr., E. Heal \& H. E. Dawson. 1985. Standards in herpetology and ichthyology: Part I. Standard symbolic codes for institutional resource collections in herpetology and ichthyology. Copeia, 1985:802-832.

Lujan, N. K. \& J. W. Armbruster. 2011. Geological and hydrological history of the Guyana Shield and historical biogeography of its fishes. Pp. 211-224. In: Albert, J.A. \& R. E. Reis (Eds.). Historical Biogeography of Neotropical Freshwater Fishes. Berkeley and Los Angeles, University of California Press, 408p.

Provenzano, F., C. Lasso \& V. Ponte. 1995. Neblinichthys roraima, a new species of armored catfish (Siluroidei: Loricariidae) from río Kukenan, Venezuela, with considerations about the biogeography of the Guyana Shield. Ichthyological Exploration of Freshwaters, 6: 243-254.

Rödder, D., A. Schlüter \& S. Lötters. 2010. Is the 'Lost World' lost? High endemism of the South American tepuis in a changing climate. Pp. 401-416. In: Habel, J. C. \& T. Assman (Eds.). Surviving on a Changing Climate - Phylogeography and Conservation of Relict Species. Berlin Heidelberg, SpringerVerlag, 464p.

Sabaj, M. H., J. W. Armbruster \& L. M. Page. 1999. Spawning in Ancistrus with comments on the evolution of snout tentacles as a novel reproductive strategy: larval mimicry. Ichthyological Exploration of Freshwaters, 10:217-229.

Schaefer, S. A. 1997. The Neotropical cascudinhos: systematics and biogeography of the Otocinclus catfishes (Siluriformes: Loricariidae). Proceedings of the Academy of Natural Sciences of Philadelphia, 148: 1-120.

Taphorn, D. C., J. W. Armbruster, H. López-Fernández \& C. R. Bernard. 2010. Description of Neblinichthys brevibracchium and $N$. echinasus from the upper Mazaruni River, Guyana (Siluriformes: Loricariidae), and recognition of $N$. roraima and N. yaravi as distinct species. Neotropical Ichthyology, 8: 615624.

Veblen, T. T., K. R. Young \& A. R. Orme. 2007. The Physical Geography of South America. Oxford, Oxford University Press, 368 pp.
Submitted April 13, 2012 Accepted October 15, 2012 by Luiz R. Malabarba Published March 31, 2013 